\title{
Sleep and immunity in times of COVID-19
}

\author{
Eduardo de Sousa Martins e Silva' \\ (iD) Ben Hur Vitor Silva Ono² \\ (iD) José Carlos Souza ${ }^{3}$
} 1. Universidade Federal do Triângulo Mineiro (UFTM), Uberaba, MG, Brasil.
2. Universidade para o Desenvolvimento do Estado e da Região do Pantanal (Uniderp), Campo Grande, MS, Brasil. 3. Universidade Estadual de Mato Grosso do Sul (UEMS), Campo Grande, MS, Brasil.

http://dx.doi.org/10.1590/1806-9282.66.S2.143

\section{SUMMARY}

BACKGROUND: Analyze how the COVID-19 (SARS-CoV-2) pandemic and its social restriction measures affect sleep quality and the immunological system.

METHODS: An integrative bibliographical review was carried out using scientific articles from the last five years, from the PUBMED databases, with the descriptors: Sleep; Quarantine; COVID-19; Immunity; Mental Health. Besides the books "Oxford textbook of sleep disorders", "Cellular and molecular immunology", and "Treaty of Infectology".

RESULTS: Sleep affects immunity. This happens through the regulation of immunological markers and their cells. Therefore, the COVID19 pandemic can promote sleep disturbances and harm the immune system function.

CONCLUSION: Sleep exercises a direct influence on immunity maintenance and immunological response. Circadian rhythm alterations, associated with the psychological problems imposed by the COVID-19 pandemic compromise the quality of sleep and, for that reason, the immune system.

KEYWORDS: Sleep. Quarantine. Coronavirus Infections. Immunity. Mental Health.

\section{INTRODUCTION}

Sleep is a vital process for maintaining homeostasis and the quality of human life. Good sleep quality has impacts on well-being and mental health. Research over the last decade has increasingly validated the claim that sleep disorders have a strong influence on the risk of infectious diseases, the occurrence and progression of a series of diseases, and the incidence of depression'.

The COVID-19 pandemic (Sars-Cov-2) not only altered the routine of a large portion of the population but also affected their quality of sleep. Much has been discussed about sleep and its immune function, something more evident when evaluating individuals under sleep deprivation, when there is an increase in the activity of cytokines, such as interferon (IFN), tumor necrosis factor-alpha (TNF- $\alpha$ ), and interleukin-1-beta (IL-1-beta), in addition to an increase of inflammatory markers such as C-reactive protein ${ }^{2}$. This contributes to the general idea that a reduction in the quality of sleep negatively affects immunity. This relationship corroborates the consequences that the changes in routine caused by the pandemic, linked to their psychosocial impact, have on the health and sleep of the population, affecting, therefore, their immune system. The purpose of this article, therefore, is to analyze the influence of sleep on the immune system during the

DATE OF SUBMISSION: 19-Jun-2020

DATE OF ACCEPTANCE: 03-Jul-2020

CORRESPONDING AUTHOR: Eduardo Silva

Rua Castro Alves, 600, Uberaba, MG, Brasil - 38025-380

Tel: +55 61 99697-7851

E-mail: eduardosousa25@gmail.com 
COVID-19 pandemic, which allows for an increase in the onset of sleep disorders correlated with a worsening of mental health, making the body more vulnerable to diseases.

FIGURE 1. FLOWCHART OF THE RELATIONSHIPS BETWEEN SLEEP, MENTAL HEALTH, IMMUNE SYSTEM, AND THE COVID-19 PANDEMIC.

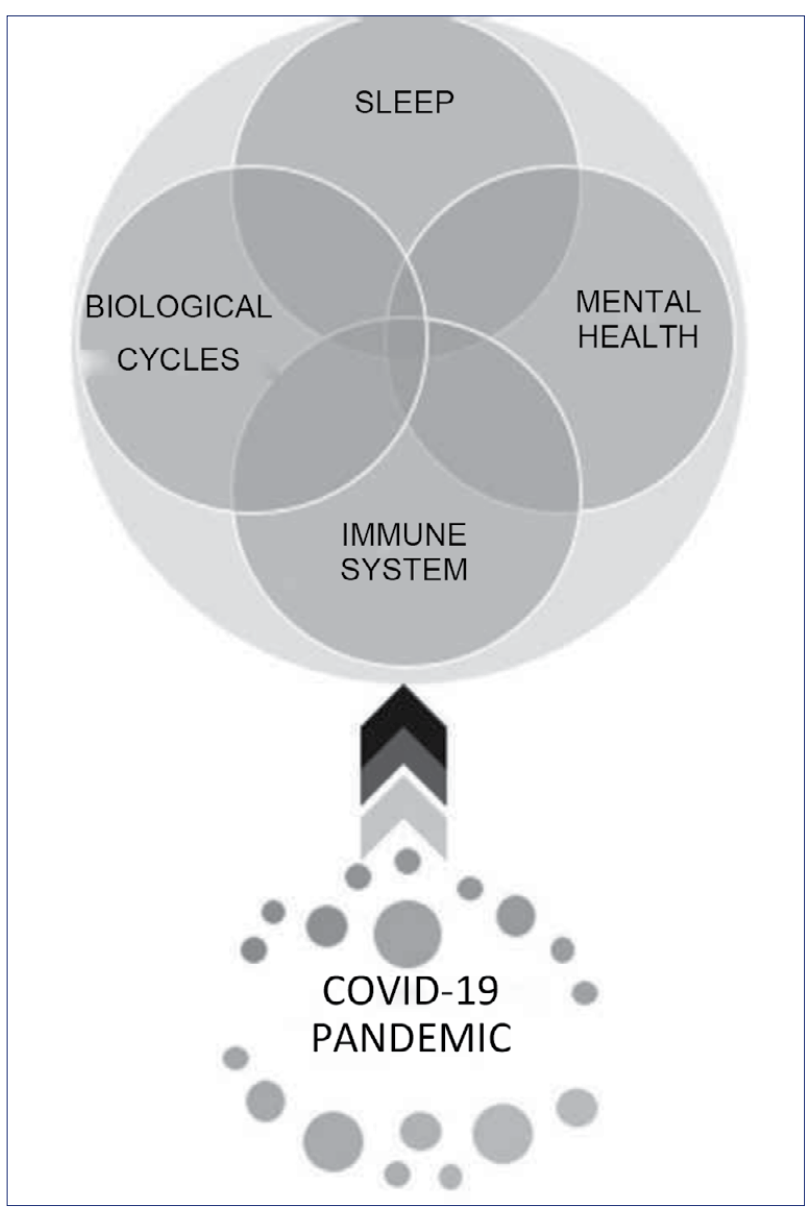

\section{Sleep and biological clock}

The perception of time is crucial for the body to adapt to the needs of each period of the day. That way, there are cycles linked to the oscillation of temperature, hormones, sleep-wakefulness, among other processes that promote the maintenance of the body's physiological systems over the course of life, and, when imbalanced, they can harm health. Disturbances of circadian cycles are involved with the onset of metabolic diseases, such as obesity and diabetes, cardiovascular diseases, and cancer ${ }^{3}$. In the same way, a lifestyle that is not in sync with the circadian rhythm or abrupt changes in routine, such as those arising from the COVID-19 pandemic, favor these disorders and are risk factors for the onset of diseases.

The process of sleep is not simply the absence of alertness and perception, nor is it the suspension of sensory processes, but the combination of a passive withdrawal of afferent stimuli to the brain, linked to functional activation of certain brain regions ${ }^{4}$. In this way, far from being a simple process, sleep, in addition to its considerable influence in regulating mood, concentration, memory, body temperature, among other processes, is also an essential regulator of the immune system and response. Lack of sleep, therefore, can negatively compromise immunity, increasing the chances of illnesses. Prather et al. ${ }^{5}$ found that there was greater susceptibility to colds related to shorter durations of sleep. There is also the influence of sleep in emotional processing, with a role in the maintenance of mood and emotional state ${ }^{6}$. In the same way, sleep deprivation can have a strong negative impact on daily behavior and, consequently, on everyday mental health.

However, excess sleep is also harmful. In addition to being associated with metabolic diseases, excess sleep (more than 10 hours per day), in comparison with lower durations, with insufficient exposure to sunlight in both cases, was associated with lower levels of circulating 25-hydroxyvitamin D (25OHD) stock $^{7}$. Vitamin D (1.25- $\left.(\mathrm{OH})_{2} \mathrm{D}_{3}\right)$, in addition to its metabolites, of which 25-hydroxyvitamin $\mathrm{D}$ is part, are actively related to immune regulation, and its deficit is linked to an increase of pathologies such as infections, autoimmune diseases, and allergic diseases ${ }^{8}$. Changes in routine, along with increased sleep time, both very common during the pandemic, can facilitate inadequate exposure to sunlight, affecting not only the metabolism of vitamin D but also the biological clock and immune system.

The sleep-wakefulness cycle acts as an "internal clock" of the human body, regulating sleep and wakefulness processes and, consequently, the various circadian cycles that influence the functioning of human metabolism. There is evidence that typical symptoms of depression can sometimes be related to disturbances of the circadian rhythms, reinforcing the notion that changes in sleep or in other cycles can affect mental health ${ }^{9}$. Some of the strategies adopted to reduce the contamination by the novel coronavirus during the pandemic, such as isolation and social distancing, dramatically change routines, which may decrease the intensity of the Zeitgebers (environmental 
cues such as sunlight, alarm clocks, and social interactions, all of which help govern the circadian cycle), thus disturbing sleep quality ${ }^{10}$.

One study showed that individuals who adopted an irregular sleep pattern were subject to a variable light pattern that encouraged delays in the circadian cycle and, consequently, could also lead to sleep delays and irregularity, suggesting a possible feedback loop ${ }^{11}$. Changes in routine, thus, facilitate the oscillation of sleep times, increasing the chances of compromising the quality of sleep. In addition, the contrast between the endogenous circadian rhythm system and the 24-hour environment cycle, both very common in those who work in irregular shifts and thus have frequent changes in routine, is a risk factor for cardiovascular and inflammatory diseases and is associated with increased blood pressure and inflammatory markers ${ }^{12}$.

\section{Immunity and sleep}

Sleep plays a unique role in the maintenance of immunity; the circumstances that affect its quality have been associated with a reduction in the response to vaccines and an increase in vulnerability to infectious diseases ${ }^{1}$. In social contexts, such as this of the COVID-19 pandemic, which naturally promote an increase in anxiety and stress, sleep can be affected and, with that, contribute to the deregulation of inflammatory and antiviral responses.

When discussing immunity, it can be divided into innate immunity and adaptive immunity, both having an important component of communication, the cytokines $^{13}$. Cytokines are proteins produced by cells of the immune system that promote intra- and intercellular immune responses ${ }^{4}$. Some important cytokines involved in sleep and in the innate immunity are the interleukin-6 (IL-6) and Tumor Necrosis Factor-Alpha (TNF- $\alpha)^{1}$. IL-6 is a pro-inflammatory cytokine that plays a role in the reduction of anabolic pathways and increase of catabolic pathways, resulting in an increased expenditure of energy to decrease the weight gain ${ }^{14}$. Whereas the function of TNF- $\alpha$, which is also a pro-inflammatory cytokine, is centered on lipolysis and in changes of the adipose tissue ${ }^{14}$, immunomodulation, apoptosis, proliferation, and pathological responses ${ }^{15}$.

In a study with people who had chronic fatigue syndrome, those who had the worst quality of sleep were associated with higher severity of fatigue and with a higher interference in daily activities, with increased levels of pro-inflammatory interleukins (IL$1 \square$, TNF- $\alpha$, and IL- 6$)^{16}$. Previous studies with groups of participants who got little slept $(<6 \mathrm{~h})$ detected a decline of $\mathrm{T}$ lymphocytes, lower activity of natural killer cells (NK), shorter telomere length of T-cells, and increased inflammatory markers (C-reactive protein and IL-6 $)^{17}$. Compared with people who slept seven to eight hours per day, those who slept less than five hours were more likely to report rhinopharyngitis and acute bronchitis ${ }^{18}$.

The impaired mitogenic proliferation of lymphocytes, decreased HLA-DR expression, positive regulation of $\mathrm{CD} 14+$, and variations in $\mathrm{CD} 4+$ and CD8+ $\mathrm{T}$ lymphocytes appear to be a possible explanation for the higher susceptibility to infections after a worsening of sleep ${ }^{19}$. Combined with this, the physiological response to psychological stressors, which can affect sleep, also proved to be able to negatively influence the immune system, demonstrating that sleep, immunity, and mental health are invariably intertwined ${ }^{20}$.

\section{Sleep disorders and the COVID-19 pandemic}

The assessment of the psychological and emotional impact of the COVID-19 pandemic in the Chinese population, during the months of January and February 2020 , clearly demonstrated the harm caused by the spread of the disease on the mental health of individuals ${ }^{21}$. The growth of COVID-19 cases has been accompanied by an increase in the levels of anxiety, stress, depression, and poor sleep quality in the population of the United States ${ }^{22}$.

Sleep disorders occur due to a malfunction of its various regulatory mechanisms. Insomnia, the most common sleep-related complaint, is a multidimensional condition, reflecting the physical and mental state of an individual. It is defined as a difficulty in initiating, maintaining, and consolidating sleep or a worsened overall quality of sleep, leading to physical and mental damage ${ }^{23}$. Depression and the widespread increase in anxiety are risk factors associated with the onset of insomnia. Excessive concern with the progress of the pandemic, their own health, or that of people close to them, and with financial aspects, in addition to social restrictions, collaborate to the impairment of sleep and, due to the role of sleep in emotional stabilization, this can impair mental health even further ${ }^{6}$. In a study performed with American soldiers from West Africa, during 2014, in the outbreak of Ebola, who were placed in quarantine, 29.8\% 
reported sleep problems ${ }^{24}$. The deterioration in the quality of sleep, therefore, should be expected at a global level during the social restrictions adopted during the COVID-19 pandemic. Even though it is difficult to measure the prevalence of insomnia in these circumstances, it is expected that there will be a large number of underreported cases of this public health problem.

When associating immunity, sleep, and depression, patients with depression, which naturally go through great psychological stress, have increased pro-inflammatory markers, particularly the marker of C protein (CRP) and IL-6. In addition, an increase in inflammation increases depressive symptoms. Moreover, sleep disorders such as insomnia are linked with the incidence of depression, in addition to promoting an increase in inflammation ${ }^{25}$.

\section{CONCLUSION}

The COVID-19 pandemic is one of the biggest challenges ever faced by world health systems in this century. Beyond the physical and geographical boundaries, the novel coronavirus greatly changed the daily lives of people; however, at the same time that measures restricting the viral infection should be a priority, the effects that emerge from these actions also need to be considered and handled. Sleep is affected in this scenario and, due to its relationship with the immune system and mental health, bad sleep impairs the immune response, facilitating the spread of infectious diseases and the worsening of mental health and quality of life.

\section{Author's Contribution}

All authors contributed equally to this work.

\section{RESUMO}

OBJETIVOS: Analisar como a pandemia de COVID-19 (Sars-CoV-2) e as medidas de restrição social afetam a qualidade do sono e o sistema imunológico.

MÉTODOS: Fez-se uma revisão bibliográfica integrativa usando-se artigos científicos dos últimos cinco anos, das bases de dados PubMed, com os descritores: Sono; Quarentena; COVID-19; Imunidade; Saúde mental. Além dos livros Oxford textbook of sleep disorders, Cellular and molecular immunology e Tratado de infectologia.

RESULTADOS: O sono afeta a imunidade. Isso se dá por meio da regulação de marcadores imunológicos e suas células. Dessa forma, a pandemia de COVID-19 pode corroborar distúrbios de sono e prejudicar o funcionamento do sistema imune.

CONCLUSÃo: O sono exerce influência direta na manutenção da imunidade e da resposta imunológica. A alteração do ritmo circadiano, atrelada aos problemas psicológicos impostos pela pandemia de COVID-19, compromete a qualidade do sono e, dessa forma, o sistema imune.

PALAVRAS-CHAVE: Sono. Quarentena. Infecções por coronavírus. Imunidade. Saúde mental.

\section{REFERENCES}

1. Irwin MR. Why sleep is important for health: a psychoneuroimmunology perspective. Annu Rev Psychol. 2015;66:143-72.

2. Ruiz FSA, Tufik S. Aspectos imunológicos do sono. In: Paiva T, Andersen ML, Tufik S, eds. O sono e a medicina do sono. Barueri: Manole;2014. p.124-31.

3. Farhud D, Aryan Z. Circadian rhythm, lifestyle and health: a narrative review. Iran J Public Health. 2018;47(8):1068-76.

4. Chokroverty S, Ferini-Strambi L. Oxford textbook of sleep disorders. Oxford: Oxford University Press; 2017.

5. Prather AA, Janicki-Deverts $D$, Hall MH, Cohen S. Behaviorally assessed sleep and susceptibility to the common cold. Sleep. 2015;38(9):1353-9.

6. Tempesta D, Socci V, De Gennaro L, Ferrara M. Sleep and emotional processing. Sleep Med Rev. 2018;40:183-95.

7. Choi JH, Lee B, Lee IY, Kim CH, Park B, Kim DY, et al. Relationship between sleep duration, sun exposure, and serum 25-hydroxyvitamin D status: a cross-sectional study. Sci Rep. 2020;10(1):4168.

8. Trochoutsou Al, Kloukina V, Samitas K, Xanthou G. Vitamin-D in the immune system: genomic and non-genomic actions. Mini Rev Med Chem. 2015;15(11):953-63.
9. Reddy S, Reddy V, Sharma S. Physiology, circadian rhythm. [Updated 2020 May 24]. In: StatPearls [Internet]. Treasure Island: StatPearls Publishing; 2020. [cited 2020 May 12]. Available from: https://www.ncbi.nlm.nih.gov/ books/NBK519507/\#

10. Guichard K, Geoffroy PA, Taillard I, Micoulaud-Franchi |-Arthur, Royant-Parola S, Poirot I, et al. Stratégies de gestion de l'impact du confinement sur le sommeil: une synthèse d'experts. Medecine du Sommeil. 2020. doi: https:// doi.org/10.1016/j.msom.2020.04.003

11. Phillips AIK, Clerx WM, O'Brien CS, Sano A, Barger LK, Picard RW, et al. Irregular sleep/wake patterns are associated with poorer academic performance and delayed circadian and sleep/wake timing. Sci Rep. 2017;7(1):3216.

12. Morris C), Purvis TE, Hu K, Scheer FA. Circadian misalignment increases cardiovascular disease risk factors in humans. Proc Natl Acad Sci U S A. 2016;113(10):E1402-11.

13. Abbas AK, Lichtman AH, Pillai S. Cellular and molecular immunology. 9a ed. Philadelphia: Elsevier; 2017

14. Veronesi R, Focaccia R. Tratado de infectologia. $5^{\mathbf{a}}$ ed. São Paulo: Atheneu; 2015. p.334-5. 
15. Holbrook J, Lara-Reyna S, Jarosz-Griffiths H, McDermott M. Tumour necrosis factor signaling in health and disease. F1000Res. 2019;8:F1000 Faculty Rev-111.

16. Milrad SF, Hall DL, Jutagir DR, Lattie EG, Ironson GH, Wohlgemuth W, et al. Poor sleep quality is associated with greater circulating pro-inflammatory cytokines and severity and frequency of chronic fatigue syndrome/myalgic encephalomyelitis (CFS/ME) symptoms in women. | Neuroimmunol. 2017;303:43-50.

17. Besedovsky L, Lange T, Haack M. The sleep-immune crosstalk in health and disease. Physiol Rev. 2019;99(3):1325-80

18. Prather AA, Leung CW. Association of insufficient sleep with respiratory infection among adults in the United States. JAMA Intern Med. 2016;176(6):850-2.

19. Ibarra-Coronado EG, Pantaleón-Martínez AM, Velazquéz-Moctezuma | Prospéro-García O, Méndez-Díaz M, Pérez-Tapia M, et al. The bidirectiona relationship between sleep and immunity against infections. I Immunol Res. 2015;2015:678164.
20. Bailey MT. Psychological stress, immunity, and the effects on indigenous microflora. Adv Exp Med Biol. 2016;874:225-46.

21. Wang C, Pan R, Wan X, Tan Y, Xu L, Ho CS, et al. Immediate psychological responses and associated factors during the initial stage of the 2019 coronavirus disease (COVID-19) epidemic among the general population in China. Int J Environ Res Public Health. 2020;17(5):1729.

22. Voitsidis P, Gliatas I, Bairachtari V, Papadopoulou K, Papageorgiou G, Parlapani E, et al. Insomnia during the COVID-19 pandemic in a Greek population. Psychiatry Res. 2020;289:113076.

23. Bacelar A. Insônia: do diagnóstico ao tratamento. São Caetano do Sul: Diffusion; 2019. p.17-27.

24. Adler AB, Kim PY, Thomas SJ, Sipos ML. Quarantine and the U.S. military response to the Ebola crisis: soldier health and attitudes. Public Health. 2018;155:95-8.

25. Irwin MR, Opp MR. Sleep health: reciprocal regulation of sleep and innate immunity. Neuropsychopharmacology. 2017;42(1):129-55. 